\title{
Health risk assessment consequent to wastewater irrigation in Pakistan
}

\author{
Maria Sabeen $^{1}$, Qaisar Mahmood ${ }^{*}$, Abdol Ghaffar Ebadi ${ }^{2}$, Zulfiqar Ahmad Bhatti $^{1}$ Faridullah $^{1}$, Muhammad Irshad ${ }^{1}$, \\ Allauddin Kakar', Muhammad Bilal', Hafiz Muhammad Arshad ${ }^{3}$ and Naeem Shahid ${ }^{4}$ \\ ${ }^{1}$ Department of Environmental Sciences, COMSATS University Islamabad, \\ Abbottabad Campus 22060, Pakistan \\ ${ }^{2}$ Department of Agriculture, Jouybar Branch, Islamic Azad University, Jouybar, Iran \\ ${ }^{3}$ Department of Management Sciences, COMSATS University Islamabad, Sahiwal Campus, Pakistan \\ ${ }^{4}$ Department of Environmental Sciences, COMSATS University Islamabad, Vehari Campus, Pakistan \\ [Received: February 07, 2019 Accepted: December 19, 2019 Published Online: February 17, 2020]
}

\section{Abstract}

The aim of this study was to investigate the uptake and accumulation of heavy metals including cadmium, chromium, iron, nickel, and lead in 8 food crops irrigated with industrial wastewater and correlate the levels with potential human health risks. The concentrations of these metals in the food crops irrigated with wastewater decreased in the order iron $(\mathrm{Fe})>\operatorname{chromium}(\mathrm{Cr})>\operatorname{cadmium}(\mathrm{Cd})>\operatorname{nickel}(\mathrm{Ni})>\mathrm{lead}(\mathrm{Pb})$. In all cases, the metallic contents in the vegetables exceeded the safe limits recommended by FAO/WHO. The highest bioaccumulation factor was recorded for cadmium. Further, the health risk indices of cadmium and lead were greater than 1 in seven food crops. For nickel, health risk was exceeded only for Pisum sativum and Solanum tuberosum. The indices for various food crops were in decreasing order: $\mathrm{Cd}>\mathrm{Pb}>\mathrm{Ni}>\mathrm{Cr}>\mathrm{Fe}$. Out of 8 food crops, only Cantiquorum antiquorum showed risk indices lower than 1 for all 5 metals. Data demonstrated that food crops irrigated with wastewater in this study area are highly metal contaminated and may constitute a serious health risk to the local human and animal populations.

Keywords: Food crops, wastewater, health risk index, metals, health risk assessment

\section{Introduction}

Lack of freshwater has compelled farmers for extensive use of wastewater for food production in various countries including Pakistan. Both freshwater and wastewaters may contain organic and inorganic compounds that benefit plant growth, but the presence of hazardous metals which exceed recommended EPA (2008)/FAO (2016) standard permissible limits might occur and consequently may induce adverse effects in animals and humans (Jaishankar et al., 2014; Iqbal et al., 2016; Chen et al., 2018b) Global concerns have been raised with respect to public health implications due to metal accumulation in crops and entrance into the food chain (Otitoju et al., 2012).

Wastewater release from industry containing pollutants including metals when used for irrigation purposes may adversely affect food quality (Singh et al., 2010; Qureshi et al., 2016). Several investigators reported adverse health risks associated with the ingestion of contaminated food containing excessive amounts of metals (Zhao et al., 2014; Kaur and Dua 2015; Liao et al., 2015; Silva et al., 2016; Chen et al., 2018a). Metal toxicity depends upon the concentration, oxidation state, exposure route, age, genetics, consumption level, and gender (Aelion et al., 2008; Barbosa 2017; Branco et al., 2017; Resende et al., 2018). Excessive concentrations of metals may result in various deleterious effects. Similarly, Ni produces allergic contact dermatitis, eczema and respiratory problems (Christensen et al., 1999; Yeganeh et al., 2013; Ahlström et al., 2018). Higher accumulation of $\mathrm{Cd}$ in humans might damage kidneys, bone and lungs (Casalino et al., 2002; Liu et al., 2014; Zhang et al., 2014; Issermann et al,2017), exposure to $\mathrm{Pb}$ may produce CNS effects, renal dysfunction and blood disorders (Liu et al., 2014; Serrazina et al., 2018; O'Connor et al., 2018; Shvachiy et al., 2018).

From human health risk assessment perspective of metals through food consumption, daily intake and metal accumulation in foods are important factors. However, the metal accumulation in food crops and associated risk

\footnotetext{
*Email: mahmoodzju@gmail.com
} 
has thus far not been comprehensively explored in areas proximal to industrial sites in Pakistan. The Environmental Protection Agency (EPA) regulations in Pakistan strictly direct the use of safe irrigation water (EPA, 2008). Although various researchers reported the risk associated with wastewater irrigation and metal accumulation in food crops globally (Arora et al., 2008; Jan et al., 2010; Gupta et al., 2013; Zhang et al., 2018; León-Cañedo et al., 2019), the consequences of ingestion of contaminated food crops to human health after longterm wastewater irrigation in Hattar Region of Pakistan still need to be addressed. Therefore, the aim of the present study was to determine the levels of heavy metals in water, soil and selected crops grown in the area irrigated with wastewater.

\section{Materials and Methods}

\section{Sample collection}

In total eight commonly used food crops viz; Colocasia esculenta L (taro), Colocasia antiquorum L (eddoe), Pisum sativum L (pea), Raphanus sativus L (radish), Rumex obtusifolius L (broad-leaved dock), Solanum tuberosum L (potato), Spinacia oleracea L (spinach) and Triticum aestivum L (wheat) were collected randomly in pre-cleaned high-density $5 \mathrm{~L}$ polyethylene bottles from fields irrigated with wastewater in May-July, 2015 from selected wastewater irrigated areas of Hattar Industrial locations involved in steel rerolling, paper mills, food industries and pharmaceutical industrial.

Briefly, soil samples were collected from three

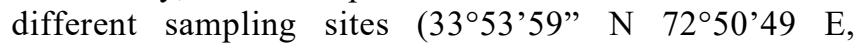
$33^{\circ} 53^{\prime} 30^{\prime \prime} \mathrm{N} 72^{\circ} 51^{\prime} 14 \mathrm{E}$ and $33.91^{\circ} \mathrm{E} 72.85^{\circ} \mathrm{E}$, $33^{\circ} 54^{\prime} 08^{\prime}$ "N 72 $\left.51^{\prime} 10^{\prime} \mathrm{E}\right)$ that have been irrigated for long-term with industrial wastewater. Surface soil (0-20 $\mathrm{cm})$ samples were collected in triplicate in a radius of 1.2 $\mathrm{m}$ as composite sample after thoroughly mixing in plastic bags (Wu et al., 2015). These samples were air-dried and sieved via a $2-\mathrm{mm}$ sieve. Thereafter, these samples were digested using mixture of $\mathrm{H}_{2} \mathrm{SO}_{4}, \mathrm{HClO}_{4}$ and $\mathrm{HNO}_{3}$ ((1:1:5 ratio) for the determination of total contents of heavy metals. Grab wastewater samples were collected in bottles from the points where fields were being irrigated with wastewater on sampling day. The samples were acidified with few drops of nitric acid to stop microbial activity.

The soil properties of the study area have been investigated by Haroon et al. (2019). According to this study, the soil pH was 7.6 8.7, EC was $554 \sim 728 \mu \mathrm{S} \mathrm{cm}^{-1}$, total $\mathrm{C}$ was in range of $22 \sim 42 \mathrm{~g} \mathrm{~kg}^{-1}$, CEC ranged 192 302 $\mathrm{mg} \mathrm{kg}^{-1}$ while its texture was loamy sand.

\section{Plant sample analysis}

Food crop samples were collected from three locations in triplicate. Briefly, edible parts of the crop were taken, washed with distilled water, oven dried for $24 \mathrm{~h}$ at $70-80{ }^{\circ} \mathrm{C}$, ground, and subsequently sieved through $2 \mathrm{~mm}$ mesh (Jamali et al. 2009). Further, $1 \mathrm{~g}$ crop samples were digested with $15 \mathrm{~mL}$ mixture of $\mathrm{H}_{2} \mathrm{SO}_{4}, \mathrm{HClO}_{4}$ and $\mathrm{HNO}_{3}$ (1:1:5 ratio) (Sigma Aldrich-St. Louis, MO 63178, USA) at $100{ }^{\circ} \mathrm{C}$ until the solution became transparent. Subsequently, transparent solution was filtered through Whatman No. 42 filter paper and the filtrate were made up to $50 \mathrm{~mL}$ volume with distilled water and stored at $4{ }^{\circ} \mathrm{C}$ for analysis. Three water samples were filtered through Whatman No. 42 filter paper, and the final volume made up with distilled water to $50 \mathrm{~mL}$.

\section{Determination of heavy metals}

Heavy metal concentrations were estimated using a graphite furnace atomic absorption spectroscopy (Model Analyst 700, PerkinElmer, Massachusetts, 02451, USA) in the Instrumental Lab, COMSATS Abbottabad, Pakistan. Standard metal solutions (1000 mg L-1) (Perkin Elmer) were diluted to make concentration ranges of $1 \sim 100 \mathrm{mg} \mathrm{L}^{-1}$. Drift and blank samples were run after each batch of four samples and all samples were analyzed in triplicate. Soil and plant standard reference materials (NIST, 2709 San Joaquin; NIST, 1547 peach leaves) of the National Institute of Standards and Technology (Gaithersburg, MD, USA) were used. Recoveries were: Cd 96\%, Cr 96\%, Fe 101\%, Ni 98\%, and Pb 97\%.

\section{Data analysis}

Statistical analyses were conducted using opensource application RStudio version 1.1.383 for Windows (R Core Team, 2017; RStudio, 2016). Metal Bioconcentration factors (BCFs) were calculated as described by Khan et al. (2010) and Li et al. (2012) using the following equation.

$B A F=$ metal concentration in edile part $/$ metal concentration in soil

The metal pollution index (MPI) was calculated taking the average of all metals in the crops by using the equation (Usero et al., 1997):

$$
\left.\operatorname{MPI}\left(\mu \mathrm{g}, \mathrm{g}^{-1}\right)=C f_{1} \times C f_{2} \times \ldots \ldots \ldots . C f_{n}\right)^{1 / n}
$$

The contamination was considered as zero, when the PI value was $\leq 1$, slight contamination when PI was $\leq 3$, moderate contamination was assumed if the PI values were in the range of 3 to 5 and the contamination was ranked as severe when the PI values $>5$. 
Daily intake of heavy metals (DIM) for individuals in the area (average weight $55 \mathrm{~kg}$ and average age 49 years) by consuming food crops was estimated according to the equation by Jan et al. (2010). Children (0-6 years old) usually consume $1 / 3$ that of adults.

\section{"DIM=(metal concentration $\times$ food intake) /(average body weight)"}

these sites, the highest water concentration of $\mathrm{Pb}$ was recorded at site 2 . Whereas, the highest water concentrations of remaining metals $\mathrm{Ni}, \mathrm{Fe}, \mathrm{Cd}$ and $\mathrm{Cr}$ were detected at site 1 . The difference in metal levels may be attributed to differing sources of wastewater such as "ghee", soap, steel manufacturing, batteries, and paint industries.

Table 1: Concentrations of $\mathrm{Cd}, \mathrm{Cr}, \mathrm{Pb}, \mathrm{Ni}$ and $\mathrm{Fe}\left(\mathrm{mg} \mathrm{L}^{-1}\right)$ in wastewater used for the irrigation of vegetable crops at different study sites and respective soils

\begin{tabular}{llllll}
\hline Sampling site & Cd & Cr & Pb & Ni & Fe \\
\hline & \multicolumn{5}{c}{ Water samples $\left(\mathbf{m g ~ L}^{-1}\right)$} \\
SITE -1 & $2.96(2.95)$ & $0.21(0.21)$ & $3.70(2.60)$ & $8.73(5.20)$ & $2.96(2.62)$ \\
SITE-2 & 0 & 0 & $6.72(3.37)$ & $0.01(0.001)$ & $0.03(0.03)$ \\
SITE-3 & $1.48(0.92)$ & $0.10(0.001)$ & $5.22(1.19)$ & $4.36(0.91)$ & $1.49(0.28)$ \\
\hline \multicolumn{5}{c}{ Soil samples $\left(\mathbf{m g ~ k g}^{-1}\right)$} \\
SITE -1 & $22.2(20.9)$ & $16.8(7)$ & $98.1(92.1)$ & $21.0(16.32)$ & $501(6.78)$ \\
SITE-2 & $5.4(4.13)$ & $33.5(11.6)$ & $17.6(12.7)$ & $5.3(2.64)$ & $501(7.28)$ \\
SITE-3 & $0.9(0.18)$ & $30.5(7.1)$ & $15.2(11.39)$ & $5.9(2.41)$ & $499.1(9.65)$ \\
Permissible limits* & 0.5 & $n / \mathrm{a}^{* *}$ & 50 & 25 & $\mathrm{n} / \mathrm{a}$ \\
\hline
\end{tabular}

Each value was the mean of three replicates and standard error was given in parentheses. *Limits described by Rowell (1994) in mg kg ${ }^{-1}, * * \mathrm{n} / \mathrm{a}^{*}$ not available.

To further assess the risk of exposure to heavy metals by consuming food crops produced in study area, Health risk indices (HRI) were estimated according to the equation described earlier (Singh et al., 2010; Pandey et al., 2012):

$\mathrm{HRI}=\frac{\sum_{\mathrm{n}}\left(\mathrm{C}_{\mathrm{n}} \times \mathrm{DIM}\right)}{\mathrm{RfD} \times \mathrm{B}_{\mathrm{w}}}$

Where $C_{n}$ is the average metal concentration in plants $\left(\mathrm{mg} \mathrm{kg}^{-1}\right)$, DIM represents the average daily intake, $R f D$ the reference oral dose, and $B_{w}$ the average body weight.

One-way ANOVA was applied to determine significant variations within wastewater, soil and vegetable samples while two-way ANOVA was applied to evaluate the significant differences between heavy metal concentrations in food crops grown in wastewater and ground water.

\section{Results and Discussion}

\section{Concentrations of heavy metals in irrigation water and soil}

Wastewater collected from three water channels in Hattar was used to irrigate different food crops cultivated on both sides of these channels. The metal contents in collected water samples are presented in Table 1. Among
Soil samples obtained from three farmlands irrigated with industrial wastewater showed higher concentrations of selected heavy metal (Table 1). Highest soil contamination in terms of $\mathrm{Cd}, \mathrm{Pb}, \mathrm{Ni}$ and $\mathrm{Fe}$ were noted at site 1 (Table 1). Whereas the $\mathrm{Cr}$ concentration was highest at site 2, and $\mathrm{Fe}$ contamination was similar at all sites. On the basis of overall metal contamination, site 1 was highly contaminated, whereas site 2 was ranked as moderately contaminated.

\section{Plant metal content}

The edible parts of food crops presented high levels of metal content (in terms of mean concentrations) in a decreasing order: $\mathrm{Fe}>\mathrm{Cr}>\mathrm{Cd}>\mathrm{Ni}>\mathrm{Pb}$. Metal uptake in food crops ranged from: $\mathrm{Fe}(180.1-506.6 \mathrm{mg} / \mathrm{kg}$, Figure 1a), Ni (1.86-17.7 mg kg-1 , Figure 1b), Pb (0.81$15.43 \mathrm{mg} \mathrm{kg}^{-1}$, Figure 1c), $\mathrm{Cr}\left(1.28-355.8 \mathrm{mg} \mathrm{kg}^{-1}\right.$, Figure 1d), and $\mathrm{Cd}\left(0.55-59.17 \mathrm{mg} \mathrm{kg}^{-1}\right.$, Figure 1e). The concentrations of heavy metals varied among different food crops as illustrated in Figure 1. Pisum sativum and Triticum aestivum contained less Fe content compared to other food crops, but highest levels of $\mathrm{Pb}$ were found in Triticum aestivum. The highest concentration of $\mathrm{Ni}$ was detected in Rumex obtusifolius. The highest concentrations of $\mathrm{Cr}$ and $\mathrm{Cd}$ were noted in Colocasia esculenta. 


\section{Bio-accumulation factor (BAF) and metal pollution index (MPI)}

The BAFs of various metals from soil to food crops are shown in Figure 2. BAF values $>1$ suggested that metal was effectively translocated from soil to plants. The range of BAF values varied for different metals. The trend of BAF (mean BAF) of selected heavy metals in differing food crops was in decreasing order of $\mathrm{Cd}>\mathrm{Cr}>\mathrm{Ni}>\mathrm{Fe}>\mathrm{Pb}$.
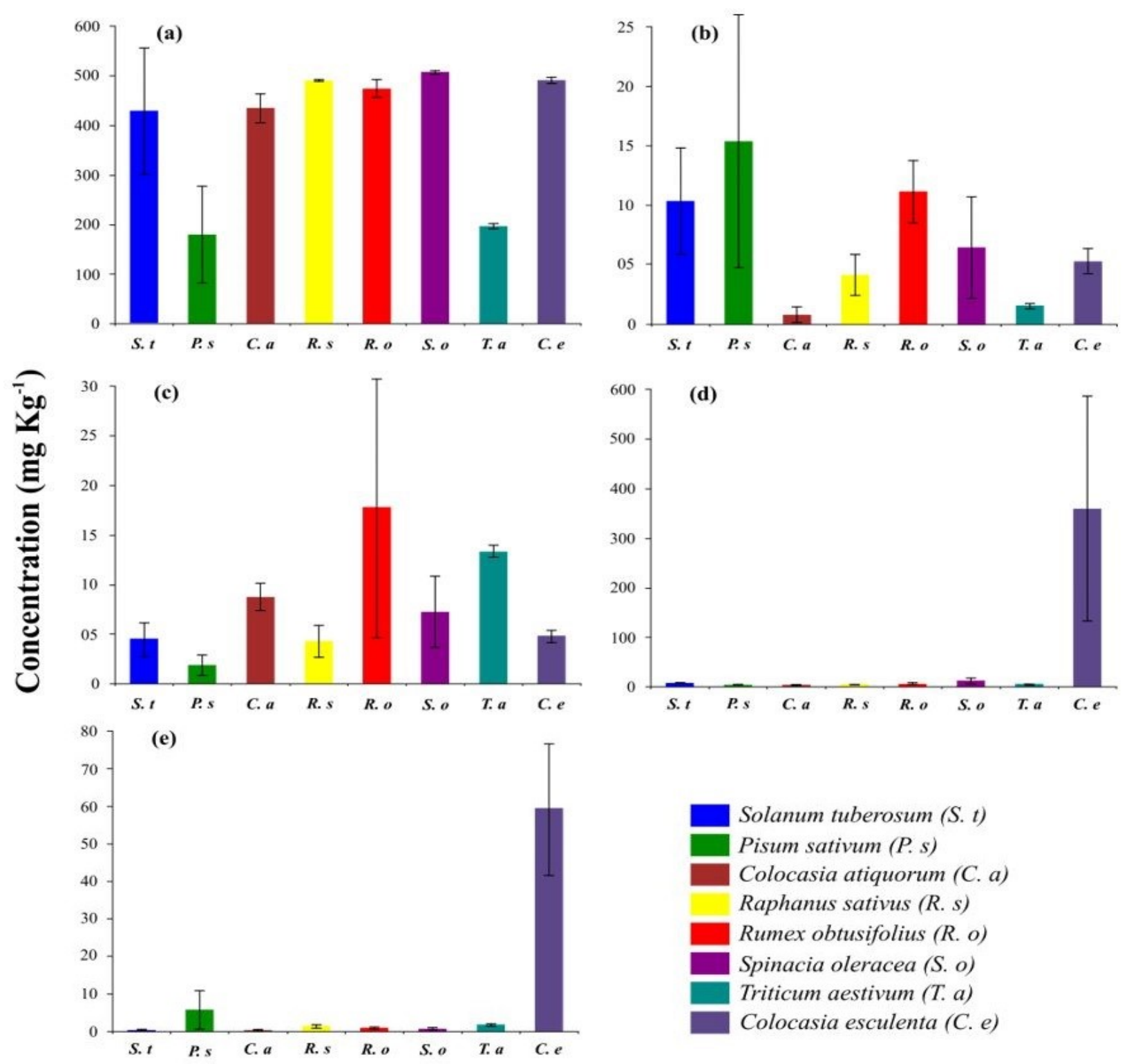

\section{Food Crops}

Figure 1: Accumulation of $\mathrm{Fe}$ (a), $\mathrm{Pb}$ (b), $\mathrm{Ni}$ (c), $\mathrm{Cr}$ (d), and $\mathrm{Cd}$ (e) in food crops with long-term wastewater irrigation. Investigated food crops are represented by different abbreviations and colours: Solanum tuberosum (S. t; blue), Pisum sativum (P. s, green), Colocasia antiquorum (C. a, brown), Raphanus sativus (R. s, yellow), Rumex obtusifolius (R. o, red), Spinacia oleracea (S. o, magenta), Triticum aestivum (T. a, cyan) and Colocasia esculenta (C.e, dark purple) 

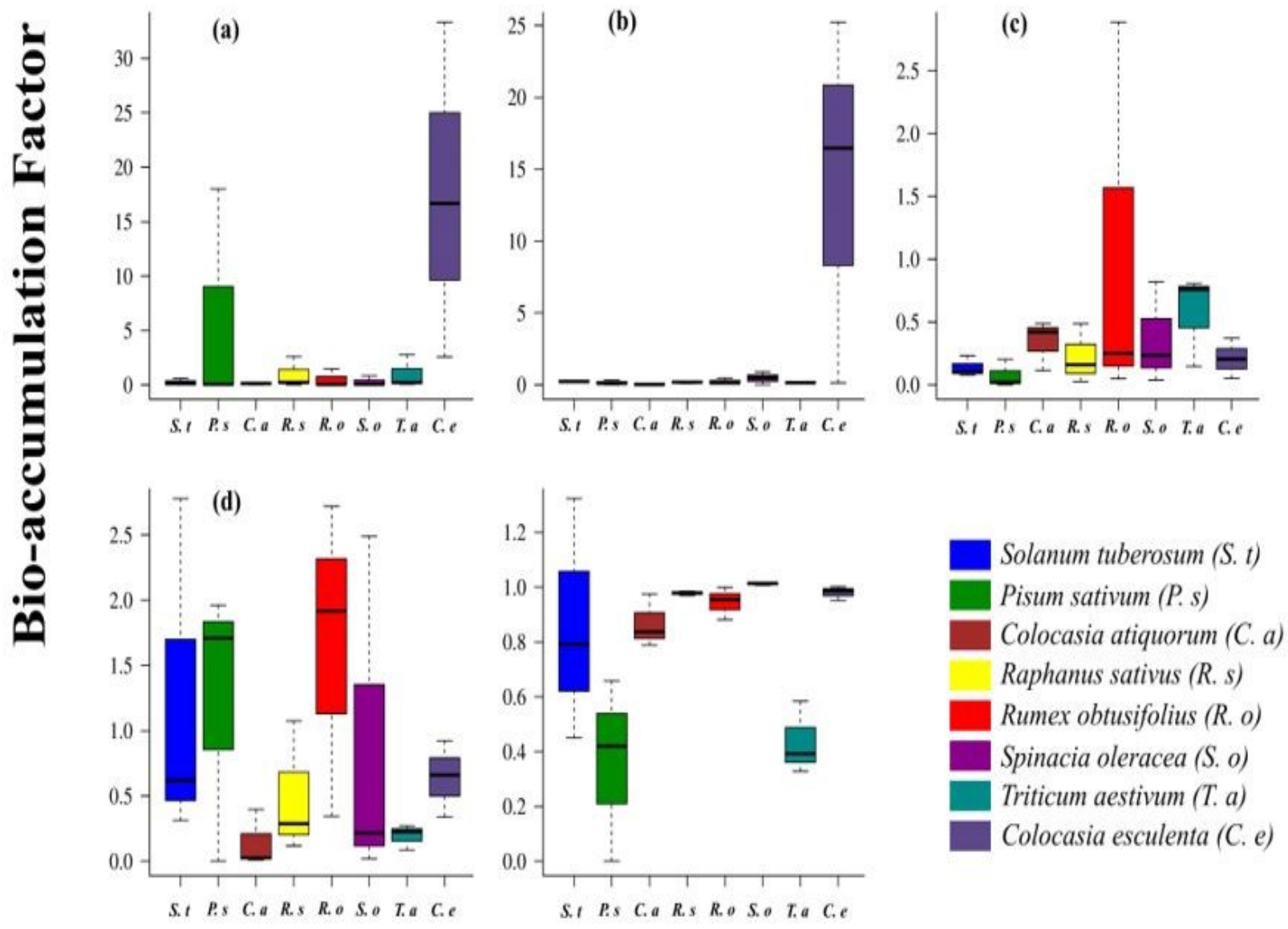

\section{Food Crops}

Figure 2: Comparison of the transfer factors of $\mathrm{Cd} \mathrm{(a),} \mathrm{Cr}(\mathrm{b}), \mathrm{Pb}(\mathrm{c}), \mathrm{Ni}(\mathrm{d})$ and $\mathrm{Fe}(\mathrm{e})$ for various vegetable crops collected from agricultural sites irrigated with industrial wastewater. Investigated food crops are represented by different abbreviations and colours: Solanum tuberosum $(S$. $t$; blue), Pisum sativum (P. s, green), Colocasia antiquorum (C. a, brown), Raphanus sativus (R. $s$, yellow), Rumex obtusifolius (R. o, red), Spinacia oleracea (S. o, magenta), Triticum aestivum (T. a, cyan) and Colocasia esculenta ( $C$. $e$, dark purple). The boundaries of the central box are the 25th and 75th percentiles; the horizontal line is the median and whiskers of the boxplot represent the minimum and maximum values

The highest accumulation of $\mathrm{Cd}$ was found in $C$. esculenta (33) $>$ followed by P. sativum (16), T. aestivum (2), R. estivum (2) and R. obstifolius (1.5); whereas all other food crops exhibited a value $<1$ which was below the permissible limit. In case of $\mathrm{Cr}$, the highest BAF quantity was noted for $C$. esculenta (25), but all other crops showed $\mathrm{BAF}<1$. BAF values for Ni were within the safe limit $<1$ except $R$. obstifolious (2.8); whereas the BAF amounts for
$\mathrm{Pb}$ were $>1$ in $S$. oleracea (2), S. tubersome (2.7) and $P$. sativum (1.7-1.9). However, bioaccumulation of $\mathrm{Fe}$ was below the acceptable limit except for $S$. tubersome (1.3). The plants metal pollution index is depicted in (Figure 3). Spinach accumulated high levels of metals (13) while radish was the lowest (5). The order of metal pollution index was $S$. oleracea $>T$. aestivum $>P$. sativum $>R$. obestosifolious $>$ C. aesculenta $>$ C. antiquorum $>R$. sativus. 


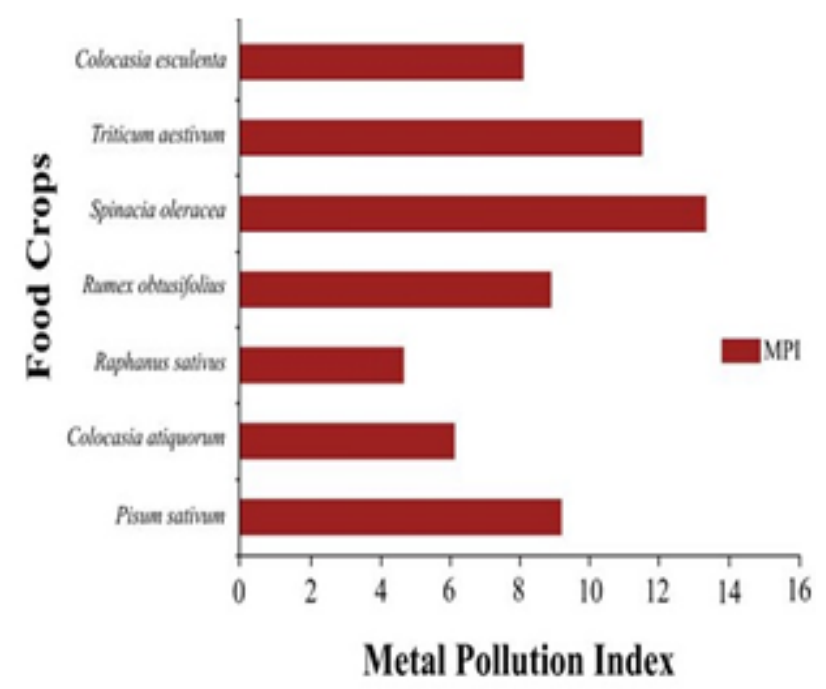

Figure 3: Metal pollution index of various crops in longterm wastewater irrigation

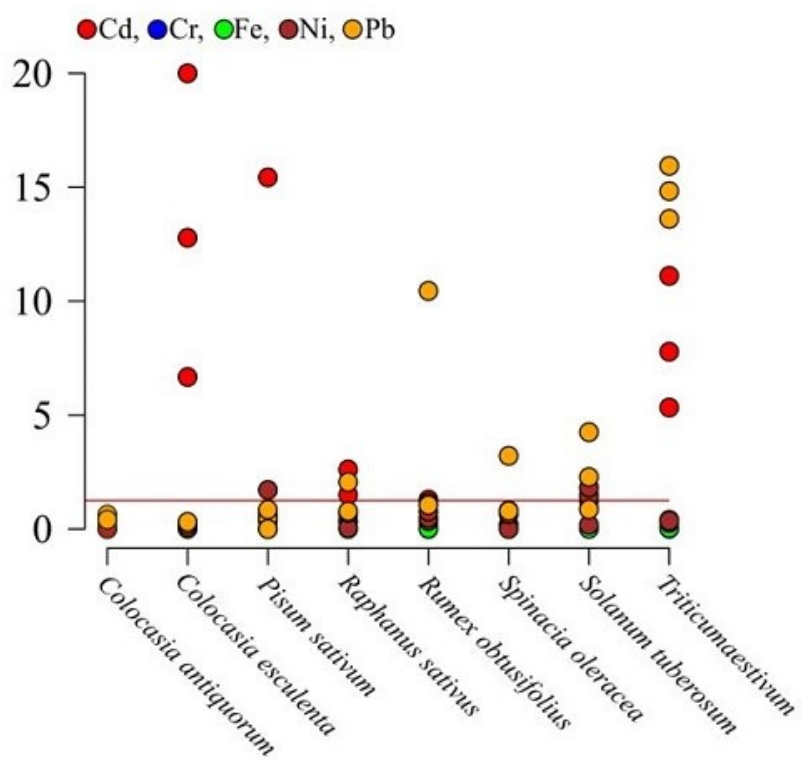

Figure 4: Health Risk Index calculated from the consumption of food crops by the population of the study area. The horizontal red line is the threshold limit for HRI (1). Points with different colors represent various heavy metals (Red; Cd, Blue; Cr, Green; Fe, Brown; Ni, and Orange; Pb)

\section{Health risk index}

In order to assess the health risk of heavy metal exposure through consumption of food crops irrigated with wastewater in the study region, HRI was determined (Figure 4). High HRI values of metals were observed in decreasing order: $\mathrm{Cd}>\mathrm{Pb}>\mathrm{Ni}>\mathrm{Cr}>\mathrm{Fe}$. $\mathrm{Cd}$ displayed the highest HRI level (20) followed by the second highest Pb (15.9). Out of 8 food crops, only $C$. antiquorum and S.oleracea exhibited HRI of $\mathrm{Cd}<1$. Whereas, lower HRI of $\mathrm{Pb}(\mathrm{HRI}<1)$ were found for only three food crops $\mathrm{C}$. antiquorum, C. esculenta and $P$. sativum. In case of $\mathrm{Ni}$, only $P$. sativum and S.tuberosum showed high risk (HRI $>1$ ). HRIs of $\mathrm{Cr}$ and $\mathrm{Fe}$ were less than 1 for all investigated food crops. There was only one food crop. C. antiquorum that demonstrated lower risk for all heavy metals.

\section{Discussion}

Data indicated an absence of a correlation between soil metal and water contamination. In some cases, metals were not detected in water samples, but these elements were present in soil. It is of interest that $\mathrm{Cd}$ and $\mathrm{Cr}$ were not detected in wastewater samples at site 2, but high concentrations were observed in the soil (Table 1). These findings may be attributed to erratic changes in effluent types and metal concentrations at that location. In most cases, $\mathrm{Cd}$ concentration in soil and water exceeded the permissible limit (MEF, 2007; Tóth et al., 2016; Vodyanitskii, 2016). Lead levels were also higher than the standard value at one site (Site 1). Although the concentrations of other heavy metals under study were below the permissible limits for soil, it should be noted that prolonged wastewater irrigation may generate metal accumulation in soils and subsequent bioaccumulation in edible parts of food crops. In comparison to other studies, most of the heavy metal concentrations in soil detected in the present study were higher than those reported in other countries (Khan et al., 2008; Liu et al., 2013; Alghobar and Suresha, 2017; Zeng et al., 2018).

In all cases, the metal content in vegetable parts exceeded the safe limits described by FAO (2016). The major source for the higher than recommended heavy metals which exceed recommended EPA (2008)/FAO (2016) standard permissible limits metal content might be related to continuous wastewater irrigation (Li et al., 2017; Chen et al., 2018a). High concentrations of Fe present in both soil and edible parts of the crops may be attributed to the soil geology of the study area, which contained an Fe-rich rock bed. The second reason of metal bioaccumulation in the vegetable crops may also be related to the original seed used in cultivation where farmers in general obtain seed from their own farmland which was previously irrigated with wastewaters. Further, plant physiology may be responsible for differences in heavy metal concentrations in food crops from identical sites due to variability in uptake, absorption exclusion, translocation within plants and accumulation (Voutsa et al. 1996; Ashok et al., 2009; Ahmad and Goni, 2010). Some specific metals may not originate exclusively 
from wastewater. It is well-established that higher levels of $\mathrm{Pb}$ in plants may be due to metallic emissions from vehicles, from the agrochemical practices in the field area or release from industry (Ndiokwere, 1984).

Transfer of metal from soil to plant is a key mechanism for human exposure through the food chain. Higher transfer coefficients are characterized by greater ability of plants for metallic uptake while lower values exhibit stronger sorption of elements with soil colloids (Coutate, 1992). The BAF is a function of both the food crops and soil properties and indicative of transfer of soil nutrients and metals from soil to plant parts (Kachenko and Singh, 2006).

According to the standard concentrations reported by $\mathrm{Wu}$ et al. (2015), the crops under investigation in this investigation were highly contaminated with metals (Figure 3). Accumulation of heavy metals in food crops is influenced by a wide range of physicochemical and environmental factors including contaminants in soil, soil properties, crop type, climate and harvesting time (Bhargava et al., 2012; Ali et al., 2013). In the present investigation, natural occurrence of heavy metals (Alam et al., 2003), lower retention in soil (Zurera et al. 1987) and continuous wastewater irrigation may constitute factors for the observed higher bioaccumulation in food crops. Data showed higher bioaccumulation of heavy metals in comparison to several other investigations (Sharma et al., 2009; Qureshi et al., 2016; Zeng et al., 2018); clearly indicating that these sites in Pakistan appear to present as a higher health risk for humans. Indeed, higher BAF values for all metals, especially for $\mathrm{Cd}$ and $\mathrm{Pb}$ are a concern for human population in this study area. It should be noted that $\mathrm{Cd}$ and $\mathrm{Pb}$ are highly toxic metals and ingestion through food chain produced adverse health issues in human population (El Fadeli et al., 2014).

The results showed that the health risk to the regional population is low with respect to exposure to $\mathrm{Cr}$ and $\mathrm{Fe}$ while consuming food crops, but the higher HRI for $\mathrm{Cd}$ and $\mathrm{Pb}$ suggest that the food crops cultivated in this region might not be safe for use with consequent serious health issues. Higher health risk of $\mathrm{Cd}$ and $\mathrm{Pb}$ effects were previously reported (Mahmood and Malik, 2014; Iqbal et al., 2016; Chaoua et al., 2018; Zeng et al., 2018; Mehmood et al., 2019). However, it is worthwhile noting that the risk level observed in the present study is several folds greater than the previous studies.

\section{Conclusions}

Concentrations of heavy metals including $\mathrm{Cd}, \mathrm{Cr}, \mathrm{Pb}$ and Fe that exceeded the permissible levels were observed in seven food crops collected from the study area. Cd displayed the highest HRI level (20) followed by the second highest $\mathrm{Pb}$ (15.9). Out of 8 food crops, only $C$. antiquorum and $S$. oleracea exhibited HRI of $\mathrm{Cd}<1$. Hence, it is suggested that farmers should not use wastewater for irrigation purposes without treatment. It is recommended that wastewater should be treated before it is used for irrigation to avoid health risk through wastewater irrigated crops.

\section{Acknowledgements}

We greatly acknowledge the contributions of Prof. Dr. Mark S. Coyne of University of Kentucky, USA to improve language of this manuscript.

\section{References}

Aelion, C.M., H.T. Davis, S. McDermott and A.B. Lawson. 2008. Metal concentrations in rural topsoil in South Carolina: Potential for human health impact. Science of the Total Environment 402: 149-156.

Ahlström, M.G., J. Thyssen, T. Menné, K. Midander, A. Julander, C. Lidén, C. Johnsen and J. Johansen. 2018. Short contact with nickel causes allergic contact dermatitis: An experimental study. British Journal of Dermatology 127: 1127-1134.

Ahmad, J.U. and M.A. Goni. 2010. Heavy metal contamination in water, soil and vegetables of the industrial areas in Dhaka, Bangladesh. Environmental Monitoring and Assessment 166: 347357.

Alam, M., E. Snow and A. Tanaka. 2003. Arsenic and heavy metal contamination of vegetables grown in Samta Village, Bangladesh. Science of the Total Environment 308: 83-96.

Alghobar, M.A. and S. Suresha. 2017. Evaluation of metal accumulation in soil and tomatoes irrigated with sewage water from Mysore City, Karnataka, India. Journal of the Saudi Society of Agricultural Sciences 16: 49-59.

Ali, H., E. Khan and M.A. Sajad. 2013. Phytoremediation of heavy metals-concepts and applications. Chemosphere 91: 869-881.

Arora, M., B. Kiran, S. Rani, A. Rani, B. Kaur and N. Mittal. 2008. Heavy metal accumulation in vegetables irrigated with water from different sources. Food chemistry 111: 811-815.

Ashok, K., I. Sharma, S. Alka, V. Sarita and P. Verma. 2009. Heavy metals contamination of vegetable foodstuffs in Jaipur (India). Electronic Journal of Environmental, Agricultural and Food Chemistry 8: 96101.

Barbosa, F.Jr. 2017. Toxicology of metals and metalloids: Promising issues for future studies in environmental 
health and toxicology. Journal of Toxicology and Environmental Health A 80: 137-144.

Bhargava, A., F.F. Carmona, M. Bhargava and S. Srivastava. 2012. Approaches for enhanced phytoextraction of heavy metals. Journal of Environmental Management 105: 103-120.

Branco, V., S. Caito, M. Farina, J.T. da Rocha, M. Aschner and C. Carvalho. 2017. Biomarkers of mercury toxicity: Past, present, and future trends Journal of Toxicology and Environmental Health B 20: 119-154.

Casalino, E., G. Calzaretti, C. Sblano and C. Landriscina, 2002. Molecular inhibitory mechanisms of antioxidant enzymes in rat liver and kidney by cadmium. Toxicology 179: 37-50.

Chaoua, S., S. Boussaa, A. El Gharmali and A. Boumezzough. 2018. Impact of irrigation with wastewater on accumulation of heavy metals in soil and crops in the region of Marrakech in Morocco. Journal of the Saudi Society of Agricultural Sciences 18: 429-436.

Chen, H., X. Yang, P. Wang, Z. Wang, M. Li and F.J. Zhao. 2018a. Dietary cadmium intake from rice and vegetables and potential health risk: A case study in Xiangtan, southern China. Science of the Total Environment 639 271-277.

Chen, L., S. Zhou, Y. Shi, C. Wang, B. Li, Y. Li and S. Wu. 2018b. Heavy metals in food crops, soil, and water in the Lihe River watershed of the Taihu Region and their potential health risks when ingested. Science of the Total Environment 615: 141-149.

Christensen, J.M., J. Kristiansen, N.H. Nielsen, T. Menné and K. Byrialsen. 1999. Nickel concentrations in serum and urine of patients with nickel eczema. Toxicology Letters 108: 185-189.

Coultate, T.P. 1996. Food, The Chemistry of its Component. 3rd Ed. Royal Society of Chemistry 54-93.

El Fadeli, S., R. Bouhouch, M. Chaik, A. Aboussad, L. Chabaa, N. Lekouch, R. Hurrell, M. Zimmermann and A. Sedki. 2014. Health risk assessment of lead contamination in soil, drinking water and plants from Marrakech urban area, Morocco. Journal of Materials and Environmental Science 5: 225-230.

EPA, 2008. National Standards for Drinking Water Quality. http://www.environment.gov.pk/act-rules/DWQStdMay 2007.pdf. (Accessed on June 26, 2017).

FAO, 2016. General standard for contaminants and toxins in food and feed (CODEX STAN 193-1995). Food and Agriculture Organization, World Health Organization. Retrieved from, http://www.fao.org/fao-whocodexalimentarius/sh-proxy/en. (Accessed November 9, 2019).
Gupta, S., V. Jena, S. Jena, N. Davić, N. Matić, D. Radojević and J. Solanki. 2013. Assessment of heavy metal contents of green leafy vegetables. Croatian Journal of Food Science and Technology 5: 53-60.

Haroon, B., A. Ping, A. Pervez, Faridullah and M. Irshad. 2019. Characterization of heavy metal in soils as affected by long-term irrigation with industrial wastewater. Journal of Water Reuse and Desalination 9 (1): 47-56.

Iqbal, H.H., R. Taseer, S. Anwar, A. Qadir and N. Shahid. 2016. Human health risk assessment: Heavy metal contamination of vegetables in Bahawalpur, Pakistan. Bulletin of Environmental Studies 1: 10-17.

Issermann, J., H.M. Prager, R. Ebbinghaus, B. Janasik, W. Wasowicz, B. Dufaux, H.F. Meyer, A. Widera, S. Selinski, J.G. Hengstler and K. Golka. 2017. Urinary cadmium levels in active and retired coal miners. Journal of Toxicology and Environmental Health A 80: 405-410.

Jaishankar, M., T. Tseten, N. Anbalagan, B.B. Mathew and K.N. Beeregowda. 2014. Toxicity, mechanism and health effects of some heavy metals. Interdisciplinary Toxicology 7: 60-72.

Jamali, M.K., T.G. Kazi, M.B. Arain, H.I. Afridi, N. Jalbani, G.A. Kandhro, A.Q. Shah and J.A. Baig. 2009. Heavy metal accumulation in different varieties of wheat (Triticum aestivum L.) grown in soil amended with domestic sewage sludge. Journal of Hazardous Materials 164(2-3): 1386-1391.

Jan, F.A., M. Ishaq, S. Khan, I. Ihsanullah, I. Ahmad and M. Shakirullah. 2010. A comparative study of human health risks via consumption of food crops grown on wastewater irrigated soil (Peshawar) and relatively clean water irrigated soil (lower Dir). Journal of Hazardous Materials 179: 612-621.

Kachenko, A.G. and B. Singh. 2006. Heavy metals contamination in vegetables grown in urban and metal smelter contaminated sites in Australia. Water, Air and Soil Pollution 169: 101-123.

Kaur, R. and A. Dua. 2015. Scales of freshwater fish Labeo rohita as bioindicators of water pollution in Tung Dhab Drain, Amritsar, Punjab, India. Journal of Toxicology and Environmental Health A 78(6): 388-396.

Khan, S., Q. Cao, Y.M. Zheng, Y.Z. Huang and Y.G. Zhu. 2008. Health risks of heavy metals in contaminated soils and food crops irrigated with wastewater in Beijing, China. Environmental Pollution 152: 686-692.

Khan, S., S. Rehman, A.Z. Khan, M.A. Khan and M.T. Shah. 2010. Soil and vegetables enrichment with heavy metals from geological sources in Gilgit, northern 
Pakistan. Ecotoxicology and Environmental Safety 73: 1820-1827.

León-Cañedo, J.A., S.G. Alarcón-Silvas, J.F. FierroSañudo, G.A. Rodríguez-Montes de Oca, L. PartidaRuvalcaba, T. Díaz-Valdés and F. Páez-Osuna. 2019. Mercury and other trace metals in lettuce (Lactuca sativa) grown with two low-salinity shrimp effluents: Accumulation and human health risk assessment. Science of the Total Environment 650(2): 2535-2544.

Li, Q., Y. Chen, H. Fu, Z. Cui, L. Shi, L. Wang and Z. Liu. 2012. Health risk of heavy metals in food crops grown on reclaimed tidal flat soil in the Pearl River Estuary, China. Journal of Hazardous Materials 227: 148-154.

Li, Y., S. Wang, D. Prete, S. Xue, Z. Nan, F. Zang and Q. Zhang. 2017. Accumulation and interaction of fluoride and cadmium in the soil-wheat plant system from the wastewater irrigated soil of an oasis region in northwest China. Science of the Total Environment 595: 344-351.

Liao, Q.L., C. Liu, H.Y. Wu, Y. Jin, M. Hua, B.W. Zhu, K. Chen and L. Huang. 2015. Association of soil cadmium contamination with ceramic industry: A case study in a Chinese town. Science of the Total Environment 514: 26-32.

Liu, G., Y. Yu, J. Hou, W. Xue, X. Liu, Y. Liu, W. Wang, A. Alsaedi, T. Hayat and Z. Liu. 2014. An ecological risk assessment of heavy metal pollution of the agricultural ecosystem near a lead-acid battery factory. Ecological Indicators 47: 210-218.

Liu, X., Q. Song, Y. Tang, W. Li, J. Xu, J. Wu, F. Wang and P.C. Brookes. 2013. Human health risk assessment of heavy metals in soil-vegetable system: A multimedium analysis. Science of the Total Environment 463: 530-540.

Mahmood, A. and R.N. Malik. 2014. Human health risk assessment of heavy metals via consumption of contaminated vegetables collected from different irrigation sources in Lahore, Pakistan. Arabian Journal of Chemistry 7: 91-99.

MEF, 2007. Ministry of the Environment, Finland. Government Decree on the Assessment of Soil Contamination and Remediation Needs. No. 214 of March 1, 2007).

Mehmood, A., W. Raza, K.H. Kim, N. Raza, S.S. Lee, M. Zhang, J.H. Lee and M. Sarfraz. 2019. Spatial distribution of heavy metals in crops in a wastewater irrigated zone and health risk assessment. Environmental Research 168: 382-388.

Ndiokwere, C.L. 1984. A study of heavy metal pollution from motor vehicle emissions and its effect on roadside soil, vegetation and crops in Nigeria. Environmental Pollution Series B, Chemical and Physical 7: 35-42.
O'Connor, D., D. Hou, J. Ye, Y. Zhang, Y.S. Ok, Y. Song, F. Coulon, T. Peng and L. Tian. 2018. Lead-based paint remains a major public health concern: A critical review of global production, trade, use, exposure, health risk, and implications. Environment International 121: 85-101.

Otitoju, O., M. Akpanabiatu, G. Otitoju, J. Ndem, A. Uwah, E. Akpanyung and J. Ekanem. 2012. Heavy metal contamination of green leafy vegetable Gardens in Itam Road Construction site in Uyo, Nigeria. Research Journal of Environmental and Earth Sciences 4: 371375 .

Pandey, R., K. Shubhashish and J. Pandey. 2012. Dietary intake of pollutant aerosols via vegetables influenced by atmospheric deposition and wastewater irrigation. Ecotoxicology and Environmental Safety 76: 200-208.

Qureshi, A.S., M.I. Hussain, S. Ismail and Q.M. Khan. 2016. Evaluating heavy metal accumulation and potential health risks in vegetables irrigated with treated wastewater. Chemosphere 163: 54-61.

Resende, A.P.O., V.S.V. Santos, C.F. Campos, C.R. de Morais, E.O. de Campos Júnior, A.M.M. de Oliveira and B.B. Pereira. 2018. Ecotoxicological risk assessment of contaminated soil from a complex of ceramic industries using earthworm Eisenia fetida. Journal of Toxicology and Environmental Health A 81: 1058-1065.

R Core Team. 2017. R: A Language and Environment for Statistical Computing. Vienna: $\mathrm{R}$ Foundation for Statistical Computing; 2013. R Foundation for Statistical Computing. (Available from http://www.rproject.org/).

RStudio, 2016. RStudio: Integrated development for R, RStudio, Inc., Boston, MA URL http://www.rstudio.com.

Rowell, D.L. 1994. Soil Science Method and Applications: Pesticides and Metals. Longman Singapore Publisher Ltd. Singapore. pp.303- 327.

Serrazina, D.C., V.L.D. Andrade, M. Cota, M.L. Mateus, M. Aschner and A.P.M. dos Santos. 2018. Biomarkers of exposure and effect in a working population exposed to lead, manganese and arsenic. Journal of Toxicology and Environmental Health A 81:983-997.

Sharma, R.K., M. Agrawal and F.M. Marshall. 2009. Heavy metals in vegetables collected from production and market sites of a tropical urban area of India. Food and Chemical Toxicology 47: 583-591.

Shvachiy, L., V. Geraldes, A. Amaro-Leal and I. Rocha. 2018. Intermittent low-level lead exposure provokes anxiety, hypertension, autonomic dysfunction and neuroinflammation. NeuroToxicology 69: 307-319. 
da Silva, R.C., S.R. Grötzner, D.D. Moura Costa, J.R.E. Garcia, J. Muelbert, V.F. de Magalhães, F. Filipak Neto and C.A. de Oliveira Ribeiro. 2016. Comparative bioaccumulation and effects of purified and cellular extract of cylindrospermopsin to freshwater fish Hoplias malabaricus. Journal of Toxicology and Environmental Health A 81(14): 620-632. doi: 10.1080/15287394.2018.1469101

Singh, A., R.K. Sharma, M. Agrawal and F.M. Marshall. 2010. Health risk assessment of heavy metals via dietary intake of foodstuffs from the wastewater irrigated site of a dry tropical area of India. Food and Chemical Toxicology 48: 611-619.

Tóth, G., T. Hermann, M.R. Da Silva and L. Montanarella. 2016. Heavy metals in agricultural soils of the European Union with implications for food safety. Environment International 88: 299-309.

Usero, J., E. Gonzalez-Regalado and I. Gracia. 1997. Trace metals in the bivalve molluscs Ruditapes decussatus and Ruditapes philippinarum from the Atlantic Coast of Southern Spain. Environment International 23: 291298.

Vodyanitskii, Y.N. 2016. Standards for the contents of heavy metals in soils of some states. Annals of Agrarian Science 14: 257-263.

Voutsa, D., A. Grimanis and C. Samara. 1996. Trace elements in vegetables grown in an industrial area in relation to soil and air particulate matter. Environmental Pollution 94: 325-335.

Wu, S., S. Peng, X. Zhang, D. Wu, W. Luo, T. Zhang, S. Zhou, G. Yang, H. Wan and L., Wu. 2015. Levels and health risk assessments of heavy metals in urban soils in Dongguan, China. Journal of Geochemical Exploration 148: 71-78.
Yeganeh, M., M. Afyuni, A.H. Khoshgoftarmanesh, L. Khodakarami, M. Amini, A.R. Soffyanian and R. Schulin. 2013. Mapping of human health risks arising from soil nickel and mercury contamination. Journal of Hazardous Materials 244: 225-239.

Zeng, L., F. Zhou, X. Zhang, J. Qin and H. Li. 2018. Distribution of heavy metals in soils and vegetables and health risk assessment in the vicinity of three contaminated sites in Guangdong Province, China. Human and Ecological Risk Assessment 24: 1-15.

Zhang, W.L., Y. Du, M.M. Zhai and Q. Shang. 2014. Cadmium exposure and its health effects: A 19-year follow-up study of a polluted area in China. Science of the Total Environment 470-471: 224-228.

Zhang, Y., C. Yin, S. Cao, L. Cheng, G. Wu and J. Guo. 2018. Heavy metal accumulation and health risk assessment in soil-wheat system under different nitrogen levels. Science of the Total Environment 622623: 1499-1508.

Zhao, Q., Y. Wang, Y. Cao, A. Chen, M. Ren, Y. Ge, Z. Yu, S. Wan, A. Hu and Q. Bo. 2014. Potential health risks of heavy metals in cultivated topsoil and grain, including correlations with human primary liver, lung and gastric cancer, in Anhui province, Eastern China. Science of the Total Environment 470: 340-347.

Zurera, G., B. Estrada, F. Rincon and R. Pozo. 1987. Lead and cadmium contamination levels in edible vegetables. Bulletin of Environmental Contamination and Toxicology 38: 805-812. 